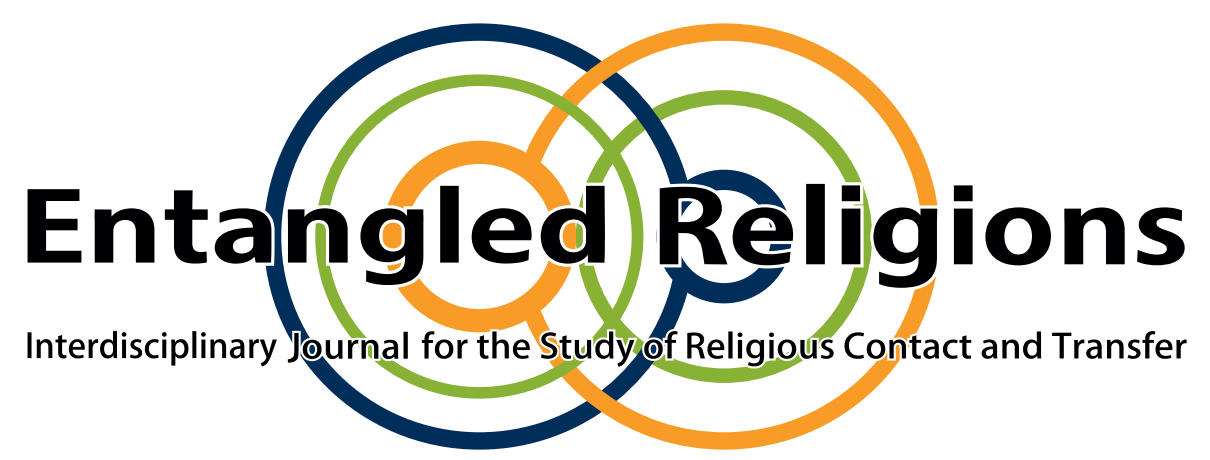

\title{
Islam and Buddhism: The Arabian Prequel?
}

ANNA AKASOY

The Graduate Center, CUNY, United States

This contribution to Entangled Religions is published under the Creative Commons Attribution 4.0 International Public License (CC BY 4.0 International). The license can be accessed at https://creativecommons.org/licenses/by/4.0/

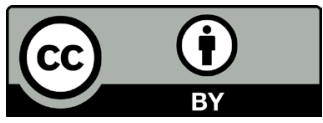
legalcode.

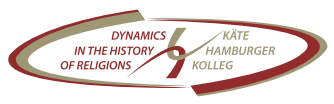
SPONSORED BY THE 


\title{
Islam and Buddhism: The Arabian Prequel? ${ }^{1}$
}

\author{
ANNA AKASOY \\ The Graduate Center, CUNY
}

\begin{abstract}
Conventionally, the first Muslim-Buddhist encounters are thought to have taken place in the context of the Arab-Muslim expansions into eastern Iran in the mid-seventh century, the conquest of Sind in 711 and the rise of the Islamic empire. However, several theories promoted in academic and popular circles claim that Buddhists or other Indians were present in western Arabia at the eve of Islam and thus shaped the religious environment in which Muhammad's movement emerged. This article offers a critical survey of the most prominent arguments adduced to support this view and discusses the underlying attitudes to the Islamic tradition, understood as a body of ideas and practices, and Islamic Tradition, understood as a body of texts. Such theories appear to be radical challenges of the Islamic tradition insofar as they seek to reinscribe the presence of religious communities in conventional narratives of Islamic origins that do not acknowledge them. On the other hand, they often operate with an unreconstructed reliance upon the sources of the Islamic Tradition. The assessment focuses on descriptions of the Ka'ba and objects associated with it as well as on a story about an Indian physician who diagnosed an illness of Muhammad's wife Aisha. While Indian or Buddhist connections with western Arabia and early Islam do not appear to be entirely impossible, the evidence does not amount to a persuasive case for the early seventh century.
\end{abstract}

KEY WORDS Islam; Buddhism; tradition

Surveys of historical encounters between Muslims and Buddhists typically begin with the Arab-Muslim expansions into eastern Iran in the mid-seventh century, the conquest of Sind in 711 and the rise of the Islamic empire. According to these accounts, it was in their home territories in the east that Muslims first came across Buddhists, or across followers of other Indian religions, for that matter. ${ }^{2}$

Authors in the medieval Islamic world, however, had different stories to tell about much earlier religious encounters between Arabs and Indians on the Arabian Peninsula and long before Muhammad's prophecy. ${ }^{3}$ Likewise, a small number of modern authors

1 Some of this research was initially conducted during a fellowship at the Käte Hamburger Kolleg "Dynamics in the History of Religions between Asia and Europe", Ruhr-Universität Bochum. I would like to thank Chase Robinson and the reviewers for their comments on earlier versions of this article.

2 Johan Elverskog, for example, identifies trade networks involving Muslims of the caliphal era as the context in which contacts with Buddhists first took place $(2010,25)$. Similarly Berzin 2010, 188, and Waardenburg 2003, 167.

3 For a survey see Friedmann 1975, 214-21. 
have suggested that Buddhism or other Indian religions were present in western Arabia on the eve of Islam. Such views present a challenge to the Islamic tradition, which acknowledges the presence of Judaism and Christianity in Muhammad's world but emphasizes the predominance of a local polytheistic and idolatrous cult which ceased to exist with the triumph of Islam. Alongside this challenge, however, sits an affirmation of the Islamic tradition as reflected in the efforts of some constituencies to inscribe or reinscribe themselves into historical narratives of the Islamic tradition.

The purpose of this article is to survey and evaluate some of the most prominent views and significant pieces of evidence for a Buddhist or Indian presence in pre- and early Islamic Mecca, their plausibility as historical theories and their implications for the Islamic tradition. The relationship between Buddhist and Indian religions is not always unambiguously clear in medieval Islamic sources, and this survey accordingly operates with both categories in a broad and sometimes overlapping sense. For medieval Muslim authors, both prominently connote idolatry. Since Muslim-Buddhist contacts in the period following the Arab-Muslim conquests in Iran are already well-explored in recent scholarship by Gimaret (1969), Elverskog (2010) and others, the focus here will be strictly on early contacts, especially in the Hijaz, although we are going to end with brief comments on the later period.

\section{Entangled Religious Histories in Medieval Arabic and Persian Literature}

In his Kitāb al-așnām (Book on Idols) Ibn al-Kalbī (120/737-204/819 or 206/821), the Kufan scholar and Arabian antiquarian, presents an explanation for the emergence of idolatry that leads the reader back almost to the earliest days of humankind. Ibn alKalbī puts the origins of idolatry in India. "When Adam died," the story begins, "the children of Seth, the son of Adam, buried him in a cave in the mountain whereon Adam alighted when he was sent to the land of India." (Ibn al-Kalbī 1952, 43-7, slightly modified) "The children of Seth", he continues later, were wont to visit the body of Adam in the cave in order to pay their respect to his memory and offer their prayers for his soul. Thereupon one of the children of Cain, the son of Adam, said, 'O children of Cain! The children of Seth have a circuit (dawār) which they circumrotate in veneration, but you have none.' Consequently he carved for them an idol, and was, therefore, the first to make graven images for worship.

From then on, the author tells us, the practice of worshipping such idols expanded. The descendants of Cain produced statues of deceased relatives and walked around them to honor their memory. Misunderstanding this ritual, subsequent generations 
followed the same tradition to solicit the statues' intercession with God. Despite warnings, they did not abandon this custom. Then, the deluge came. "Two thousand and two hundred years intervened between Adam and Noah. The flood washed down these idols from the top of Mount Nawdh to the land below; and as the waters raged and the billows swelled, the idols were tossed here and there until at last they were cast by the way on the land of Juddah [i.e., Jedda, the port of Mecca]. When finally the waters receded, the idols were left on the coast [of the city]. In time they were covered by the sands, which the winds blew over from the shore." Eventually, 'Amr ibn Luhayy, a Meccan religious authority, was instructed by "an oracle of the jinn" to go to Jedda, find the idols and take them back with him and ask the Arabs to worship them.

Ibn al-Kalbī was not the only medieval Muslim author who claimed that Indian religion had a much greater presence in the pre-Islamic Middle East and Arabia than is nowadays commonly believed. More than two centuries after him, al-Bīrūnī (362/973 - after 442/1050), the author of one of the most significant books about India written by a non-Indian in the premodern period, has the following unusually detailed account to offer:

Another circumstance which increased the already existing antagonism between Hindus and foreigners is that the so-called Shamaniyya [commonly understood as Buddhists, see below], though they cordially hate the Brahmans, still are nearer akin to them than to others. In former times, Khorasan, Fars, Iraq, Mosul, the country up to the frontier of Syria, was Buddhist, but then Zoroaster went forth from Azerbaijan and preached Zoroastrianism in Balkh. His doctrine came into favor with King Gushtasp, and his son Isfendiyar spread the new faith both in east and west, both by force and by treaties. He founded fire-temples through his whole empire, from the frontiers of China to those of the Greek empire. The succeeding kings made their religion [i.e., Zoroastrianism] the obligatory state-religion for Fars and Iraq. In consequence, the Buddhists were banished from those countries, and had to emigrate to the countries east of Balkh. (Al-Bīrūnī 1910, I, 21, slightly modified)

Al-Bīrūnī's account is remarkable not only for the insights he allows into how an exceptionally well-informed medieval Muslim author may have understood the difference between Buddhists and other Indians, but also for his claims concerning the spread of Buddhism towards the west, although he does not specify the ultimate extent of Buddhist migration. While acknowledging the possibility of Buddhist influences in Greece, especially in Hellenistic contexts, the common view in present-day scholarship 
establishes Iran as the border of Buddhist westward expansion. ${ }^{4} \mathrm{Al}$-Bīrūnī extends this border even further to the west and seems to imply that Buddhists were predominant rather than merely present.

Three centuries later, another unusually well-informed author, the Ilkhanid vizier Rashīd al-Dīn (ca. 645/1247-718/1318), included a similar statement in his History of India, part of his world history. According to him, Buddhism had expanded even further to the west and to the south:

The twentieth section about the descriptions of the religions of the lands and places of India. As for the people of Sarandib [= Sri Lanka], they are followers of the religion of Shākyamūni [i.e., Buddhists] and they belong to the sect of the Shravakas. As for the people of the lands of Mahābudh [= Mahābodhi], where Shākyamūni was born and which lies in the centre of India, some of them are followers of Shākyamūni and some of them followers of Māheshvara. As for the people of the kingdom of Mass [Mansi? = Man-tze] which is close to Khițā, their shape is similar to the shape of the people of Khițā, except that their ears are cut. It is a flat and wide land. All of them are followers of Shākyamūni, and they belong to the sect of the Shravakas. As for the people of Qandahar, which is called Qarājang by the Mongols and which is a wide and unapproachable land, their appearance is similar to that of the people of Khițā. Their ears are cut and they are all followers of Shākyamūni. As for the people of the land of Kaud [= Bengal], they are pure Indians. There are five provinces [in the Arabic version of the text: works], each one of them called Kaudi. Every Kaudi has the size of Iraq and Khurasan or of Syria and Egypt. The people have different religions. Some of them are followers of Shākyamūni, others of Māheshvara. As for the people of Malībār [= Malabar], Kawā [= Goa], Tānā, Ma'bar, Dalank, Kadmad [= Katmandu], Mālawa, Khararāt [= Gujarat], Sind and Delhi and the people of the lands of the Turks from the Tibetans, Tanguts, Uygurs, Khay [= Khitāi] and China, they all mix the religions, except for (?) the Tibetans and Tanguts, for they have a pure religion and follow the doctrine of Samīk Samand [= Samyaksambuddha]. As for the people of inner and central Ethiopia and some black people, they follow the path of Shākyamūni. As for the people of the north and the regions which stretch out to the darkness, their inhabitants are women who sometimes steal men for reasons of procreation and breeding. It is a peculiarity of these regions that if a man

4 For general accounts see Webb 1993, Seldeslachts 1997, Halkias 2013. Patricia Crone explained these accounts as a combination of the actual integration of Buddhist elements into Iranian religion and later conflations. Who integrated these elements into the historiography of Iranian religion, at what point this happened, and under which circumstances, however, remains unclear. As Crone herself acknowledged, her assessment relied on conjecture (Crone 2012). 
hears there the sound of thunder, he dies instantaneously. For this reason, they [= the women?] bring them to cellars where the sound of thunder does not reach them. All these women follow the religion of Shākyamūni. It has been mentioned that the people of Mecca and Medina and some Arabs and Persians followed the religion of Shākyamūni before Islam and that there were idols in the idol house [= the Ka'ba] in the shape of Shākyamūni in front of which they bowed down. Our prophet Muhammad-God bless him and grant him salvation-ordered that the idols should be destroyed and he asked the people to become Muslims. As for the people of Kashmir, they belong to the community of Māheshvara, and some of them follow Brahma. As for the Turks, all of them are followers of Shākyamūni, but in these days many of them have converted to Islam. ${ }^{5}$

All three authors offer premodern versions of entangled histories. Similarities between cultural practices are not accounted for from a phenomenological or anthropological point of view, as if they manifested underlying universal human dispositions. They are rather taken to reflect actual contacts between communities set apart by language, religion, political rule and geographical distance. Some authors connected Mecca and India additionally as functional equivalents, that is, as archetypical centers of idolatry. The eleventh-century writer Gardīzī, for example, explained that Somanātha "was venerated by the Indians just as the Muslims venerate Mecca". For the Persian historian, however, this too involved more than merely a functional parallel. "It contained numerous idols of gold and silver, and the idol Manāt, which had been transported from the Ka'ba by way of Aden in the time of the Lord of the World (i.e. Muhammad), was there." (Gardīzī 2011, 96) ${ }^{6}$ As Richard Davis has argued, Muslim sources envisioned Somanātha as the capital of Indian idol cults since "when confronting the polycentric Indian political and religious order ... Muslim chroniclers wished and needed to identify a center, the Indian equivalent of Mecca or the caliphal Baghdad" (Davis 1999, 94). As Davis explains, as Somanātha became a paradigm for idolatry, Maḥmūd of Ghazna, who raided the temple in 416/1026, was modelled after the paradigm of the prophet who destroyed the idols in the Ka'ba. ${ }^{7}$ (We will return to this episode in the Islamic tradition below.)

5 Chapter twenty in the Persian version of the History of India. The Persian manuscripts Istanbul, Topkapı Sarayı, Hazine 1654, and British Museum Add. 7628 are reprinted in Jahn 1965 and Jahn 1980. For the Arabic text see the reproduction in Blair 1995. See also Akasoy 2013, 187.

6 See also Parekh 1954, 292. See Davis 1999, 95, for the Muslim etymology of Somanātha as derived from Manāt. According to this explanation, worshippers of the Meccan deity Manāt left Arabia after Muhammad told Ali to end the cult there and ended up in Gujarat.

7 For the presence of Muslims in Somanātha before Maḥmūd see Shokoohy 2012. 
Among modern scholars, the two different approaches to the relationship between Arabian and Indian religion, entanglement and functional equivalence, elicit different responses. While observations of the latter kind might qualify as a premodern exercise in comparative religion, theories about contacts are usually identified as legends. They might be explained as Muslim endeavors to explain any human culture in terms of Muhammad's environment and hence the paradigmatic function of the Islamic tradition (Friedman 1998; Akasoy 2012). As such, these attempts to establish a historical connection between Arabian and Indian idolatry and polytheism exemplify important features of the Islamic tradition. Scholars of Islamic history and culture tend to use the phrase "Islamic tradition" in either of two ways. In a narrower, more technical sense, it denotes a body of texts, primarily hadiths or so-called "prophetical traditions". These reports of sayings and deeds of the prophet Muhammad typically consist of a text (Arabic: matn) and a chain of transmitters (Arabic: isnād) which was meant to demonstrate reliable and accurate recording and transmission from the time of Muhammad, who died in 632, to the time collections of hadiths were compiled in the eighth and ninth centuries. It is in this time that what were to become the canonical collections were assembled and that the prophetic model as recorded in these texts and other biographical material had gained a normative function in Islamic law. Patricia Crone and Martin Hinds described this development as Muhammad turning from a prophet to the Prophet (Crone and Hinds 1986, 27-9). Following their example, one may refer to the corresponding biographical texts as the Tradition. Islamicists also use the expression "Islamic tradition" in a broader sense to denote a more amorphous body of beliefs, concepts and practices which are widespread among Muslims of different time periods and geographical areas. For the present purposes, this will be referred to as the "Islamic tradition" with a lower-case " $\mathrm{t}$ ". It is mostly inclusive of Tradition.

The relationship between Tradition and tradition is dialectical. While Tradition provides a reference point for tradition in many respects, Tradition was only canonized a century or two into Islamic history and had been subject to the transformations involved in the rise of the Islamic empire and thus evolving tradition. Furthermore, tradition informs the interpretation and application of Tradition. Just how malleable both Tradition and tradition are is obvious from geographical references in Islamic history where the later boundaries of the Islamic empire and commonwealth were projected back in time. The transition of Alexander the Great into an Islamic quasiprophet whose exploits extended to the Iberian Peninsula illustrates this well (Akasoy 2016), but the Arab-Indian entanglements in religious history do so as well. While these developments may have left the Islamic tradition open to challenges regarding the authenticity or accuracy of its historical accounts, they also strengthened the tradition. Muslims outside of the Middle East were able to inscribe themselves (or were otherwise 
inscribed) into the landscape of early Islamic history with their own geography, ethnicity and culture. As the western Arabian setting became normative throughout a rapidly expanding Islamic world, its deeper roots were recognized as already globalized. From the point of view of authors such as Ibn al-Kalbī, Indian influences on the religious landscape of pre-Islamic Mecca were thus not a challenge to the Islamic tradition.

This, however, is different among a number of modern authors who claim that Indian religions, or more specifically Buddhism, were more present in western Arabia than the Islamic tradition would have it and that that fact of history may have been edited out in the Islamic tradition. While the impact of Buddhist or Indian doctrines and practices on Islam is relatively well-acknowledged for secondary periods of Islamic history-that is, after the first century - theories of Buddhist or Indian presence in western Arabia on the eve of Islam are usually not discussed by professional historians. Still, there are lines of some recent scholarship (as well as literature within the larger orbit of academia and more popular literature) that suggest that religious contacts indeed took place between Indians and west Arabians before Muhammad's prophecy. A small number of authors argue for either Buddhist or Vedic/Hindu influences on emergent Islam.

Extensive arguments have been presented especially by two authors. In his wideranging Buddhism in Iran, Mostafa Vaziri suggests on several occasions that Buddhism was present in western Arabia in one way or another (Vaziri 2012). Markus Groß surveys evidence in a more focused way in his articles "Buddhistische Einflüsse im frühen Islam?" ("Buddhist Influences on Early Islam") and "Frühislam und Buddhismus. Neue Indizien" ("Early Islam and Buddhism. New Evidence") (Groß 2008; Groß 2009). The third author discussed here is Manjul K. Agarwal, who argues for Indian influences on early Islam in several publications.

A word is in place concerning the methodological commitments of these authors. Vaziri is the least controversial of the three named here. His survey relies on widelyaccepted historical, philological and anthropological scholarship. Historians should take particular note that Vaziri presents his study explicitly as an anthropological investigation. What exactly this implies unfortunately remains somewhat unclear. Striking similarities between religious and cultural practices are perhaps taken as sufficient grounds for assumptions of influence, where historians might expect a more compelling demonstration of contacts and transmissions. For the present purposes, however, Vaziri's suggestions will be treated as historical assertions, since they are ultimately presented as true claims about the past.

Agarwal is less widely known. His two-volume From Bharata to India is unabashedly presented as a nationalistic representation of Indian history. WorldCat does not list a single copy available in North American libraries. Portions of Agarwal's books, however, are available on Google Books and they will be treated here as a representative version 
of views frequently found on non-academic blogs and other online media. These are some of the most prominent voices on Muslim-Buddhist historical contacts and some of the evidence adduced should appear intriguing to academics as well.

Markus Groß's academic commitments put his publications at the margins of professional scholarship on early Islamic history. As a member of the INARAH group, the author shares the view that Islam did not emerge in early seventh-century western Arabia, but about a century later in eastern Khurasan. This is not the place to discuss the widely diverging views on the emergence of Islam and historiographical uncertainties (Robinson 2010). Suffice it to say that the position of many members of the INARAH group is the result of a radical reformulation of early Islamic history among Western scholars since the 1970s. John Wansbrough, in particular, is credited with casting fundamental doubts on the then prevailing narrative of Islamic origins, which relied on Muslim sources produced in the eighth century (or later), and with offering alternative models. These scholars illustrate in which ways the long duration of its formation and canonization left the Islamic Tradition vulnerable to challenges to the authenticity of the historical narratives it contains. It is important to emphasize here just how critical history is to the Islamic tradition. For while Muhammad's prophecy had a supernatural component, initiated as it was by an encounter with the archangel Gabriel, Muhammad's prophetic career unfolded in a human and historical milieu. The Islamic Tradition offers both a plot and, critically, a setting. Historians often identified as "revisionists" challenged conventional accounts which had not taken the intricate relationship between Tradition and tradition into account, arguing, for example, that for polemical reasons Christian and Jewish influence upon Islam is understated by Islamic sources and that authors such as Ibn al-Kalbī imagined a vibrant religious culture of polytheism and idolatry in order to reduce the already strong presence of monotheism. Gerald Hawting, for one, has argued that the early Muslim criticism of idolatry reflects, in origin, polemical tropes figuring in a monotheistic milieu. Important for our purposes is the implication that by turning Christians and Jews into polytheists and idolaters, later generations of Muslims tried to counter or anticipate accusations that Muhammad's prophecy was in fact merely an adaptation of Christian and Jewish ideas and practices. Influence here implies indebtedness and negates originality. The same challenge drives some theories about Buddhist or Indian influences on early Islam. Not every theory of influence, however, needs to imply a challenge to the significance the Islamic tradition attributes to its historical narrative and metaphysical claims. Ideas and practices rejected by Muhammad can be said to have had an influence on emerging Islam insofar as they determined explicit condemnation, rejection and prohibition.

Neither Hawting nor Patricia Crone, another so-called revisionist whose work figures here, made a case for Buddhist influences on early Islam during the first century. But 
insofar as it contributes to the project of interrogating fundamental assumptions about the cultural and religious complex of the first century, revisionism opens the possibility of radical reframings of the historical narratives embedded in the Islamic tradition. As mentioned above, for some revisionists the "sectarian milieu" in which early Islam emerged was not seventh-century Arabia but Abbasid Iraq and Khurasan. The assumption that Islam is a product of Merv rather than Mecca obviously makes the challenge of demonstrating a Buddhist influence an altogether easier task. Groß, however, appears to make larger claims; and since his articles focus, in large part, on the pilgrimage to Mecca, his views will be treated as part of a theory of Buddhist influences in western Arabia.

\section{Hāritī in the Ka'ba?}

Religious objects and rituals in and around the Ka'ba are regularly adduced as evidence for Buddhist or, more generally, Indian influences on early Islam. In and of itself, the case for connections between India and Arabia is not hard to make. The immensely interconnected nature of Eurasian cultures since antiquity is now widely documented. Trade features prominently in accounts of exchanges and other contacts between communities separated by language, religion, ethnicity and socio-economic or political formation. While the Silk Roads serve as a bracket for such contacts across the large territories from the Mediterranean to East Asia, two other phenomena are critical for the theory of a Buddhist presence in western Arabia on the eve of Islam: the Indian Ocean trade and Meccan trade.

Trade around the Indian Ocean and between the Indian Ocean and the Mediterranean predates the rise of Islam by centuries, as one can easily glean from scholarship concerning the relationship between ancient Rome and India (Casson 1989; Begley and de Puma 1991; Reade 1996; Chakravarti 2001; Parker 2002). This trade gave rise to relatively cosmopolitan milieus in southern Arabia and the Persian Gulf and accounts for the presence of Indians in these areas. To what extent these conditions also obtained in western Arabia is a separate issue. The Arabian Peninsula was, after all, not a uniform cultural and political landscape. Trade between the Indian Ocean and the Mediterranean almost naturally involved the Red Sea. ${ }^{8}$ The extent to which this connection was active at specific points in time, as well as the relationship between 
Mecca and any Red Sea ports, complicate assumptions about any significant and continuous Indian presence in western Arabia. ${ }^{9}$

Ritual circumambulation, common to both Muslim and Buddhist religious practice, is sometimes seen as the most significant and obvious legacy of Indians in western Arabia. The similarities between Muslim and Buddhist circumambulation were not lost on medieval Muslim authors who sought to account for them with stories of contacts. In the above-cited Book of Idols, Ibn al-Kalbī explains not only the origins of idol worship, but also the practice of circumambulation as rooted in India. In his history of the Barmakids, written at the very beginning of the ninth century, Abū Hafș 'Umar al-Kirmānī compared the Buddhist rituals surrounding the stupa of Nawbahar with the Muslim pilgrimage to Mecca and claimed that the former was inspired by the latter (van Bladel 2011, 60-74; Bosworth 1994; Melikian-Chirvani 1984). Accounts of such connections are not prominent in medieval narratives. According to the Islamic tradition, Muhammad simply continued, and thus validated, a preexisting practice which had emerged from local circumstances (Buhl 2012). The cult around the Ka'ba is commonly attributed to Abraham. Among some modern authors, however, these parallels in ritual are indeed taken as reflecting earlier contacts between Buddhists and Meccans (Vaziri 2012, 82-4, 92, 95, 102-5; Groß 2008, 249-50). ${ }^{10}$ Markus Groß presents one of the most detailed comparisons, which in their cumulative effect he sees as so distinctive as to betray Buddhist influences in western Arabia. ${ }^{11}$ The argument is unpersuasive. While Muslim and Buddhist ritual circumambulation constitute indeed some of the best-known examples of the practice, Diana Eck has surveyed examples of Hindu, Jewish as well as native American ritual circumambulation and observes that "circumambulation is a fundamental rite of orientation, and is often thought of as a human repetition of the apparent movement of the sun" (Eck 2005). In fact, the practice of țawāf (circumambulation) is also attested for pre-Islamic south Arabia. ${ }^{12}$ This explanation can be reconciled with theories of earlier Buddhist influences, but the reconciliation is inefficient and extraneous.

9 For a survey see Seland 2017. For problems of identifying the port of Mecca see Hawting 1984. One of the difficulties surrounding al-Shu'ayba is that the story about the rebuilding of the Ka'ba is one of the few instances where this port is mentioned. For a general overview see Power 2012. For a skeptical assessment of the presence of Indian goods in western Arabia see Crone 1987.

10 In the article by Groß, circumambulation is but one aspect of a longer comparison between Muslim and Buddhist pilgrimage practices (see pages 240-57), a cornerstone in his argument for Buddhist influences. See also Webb 1993, 67, and Siddiqi 1970, 586.

11 How Groß's larger historiographical commitments apply here remains unclear. His assumption may be that such Buddhist influences took place in eastern Iran and were then implemented in Mecca.

12 For the țawāf stone see Beeston 1948. For the relevant term, see the entries on qyf in the Corpus of South Arabian Inscriptions, where the word is mostly translated as stela. 
Apart from this ritual associated with the Ka'ba, the physical shape of the sanctuary has attracted the attention of authors who argued for the presence of Buddhist or Indian cults in western Arabia at the time Islam emerged. They have found an especially promising lead in the paintings which reportedly existed inside the Ka'ba. The Islamic tradition has it that in 630 or so Muhammad smashed 360 idols kept in the sanctuary and removed its paintings. ${ }^{13}$ (This is the action emulated by Mahmūd of Ghazna referred to above.) The paintings may have dated only to about 608 , when the Ka'ba had burned down due to an accident. Al-Azraqī, the ninth-century author of a history of Mecca, offers a detailed account of the reconstruction, in which a carpenter named Bāqūm plays a critical role. Bāqūm, perhaps an Ethiopian man who was in one way or another affiliated with the Byzantine Empire (hence "al-Rūmī", i.e., "the Roman"), had been shipwrecked in the Red Sea and ended up in Mecca:

Bāqūm al-Rūmī said to the Quraysh: 'Do you want the roof [of the Ka'ba] pitched or flat?' 'Rather build the house of our Lord ( $r a b b)$ flat.' He [apparently al-Azraqi's grandfather, Aḥmad ibn Muhammad al-Azraqī] said: 'So they built it flat and they put in it six columns in two rows: in each row were three columns from the northeast corner where is the [Black] Stone, to the southwest corner, and they made its external height from the ground to its summit eighteen cubits high, and previously [the pre-Quraysh Ka'ba] had been nine dhirā' high. The Quraysh added another nine dhirā' to the upper part, and they built it from the top to the bottom with courses of stone and courses of wood, and fifteen courses were of wood and sixteen courses were of stone, and they fixed its water-spout that pours forth [water] in stone, and they placed wooden steps inside it at the northeast corner to ascend by them to its rear, and they decorated its ceiling and its internal wall surfaces and its columns, and they put on its columns pictures of the Prophets, pictures of trees, and pictures of the angels. There was a picture of the prophet Ibrāhīm Khalīl al-Raḥmān [i.e., Abraham] with divining arrows, and a picture of 'Īsā ibn Maryam and his mother [i.e., Jesus and Mary], and a picture of the angels, upon them be peace, all of them. And when it was the day of the conquest of Mecca, the Prophet (peace be upon him) entered, and he sent off al-Faḍl ibn al-'Abbās ibn 'Abd al-Mutțalib [his cousin] to come with water from [the well of] Zamzam. Then he called for a cloth, and he ordered [them] to rub off these pictures, and they were obliterated. (King 2004, 219-20 simplified)14

13 King 2002a and 2002b. King does not consider Indian origins for these sculptures but focuses on Arabian or Byzantine sources. See also King 1980.

14 For the Arabic text Al-Azraqi (1403) 1983, I, 165. See also 157 for the account of Bāqūm's shipwreck in al-Shu'ayba. For Bāqūm see also Power 2012, 91-2. 
As can be seen here, when Muhammad returned victoriously to Mecca in 630 , he reportedly restored the Ka'ba to what the Islamic tradition claims had been its pristine monotheistic form, although he reportedly spared a painting of the Virgin Mary with baby Jesus. In 683 , the Ka'ba was again destroyed, this time in the civil war between Ibn al-Zubayr and the Umayyads.

Vaziri adduces two elements in the history of the Ka'ba during the seventh century for his argument for Buddhist influence: the shape and the idols. The new, flat roof of the building he takes to be a "post-Islamic innovation", which disguised the original dome that was modeled after Buddhist shrines (Vaziri 2012, 93). But he appears to conflate the two destructions of the Ka'ba: al-Azraqi describes the change from dome to flat roof as a development in Mecca before Muhammad's prophecy. This sequence, however, appears to be fairly easily reconcilable with Vaziri's larger argument about a Buddhist legacy which was gradually forgotten or edited out of the Islamic tradition. Either way, if we assume that after the first seventh-century destruction of the Ka'ba, the local leaders received support from an expert with a Byzantine background, the dome is not hard to explain as Bāqūm's potential default choice for a roof. Domes also marked the shape of Byzantine religious architecture, after all, and the Meccans may just as well have wanted to differentiate themselves from Byzantine Christians with their preference for the flat roof. ${ }^{15}$

Independent of the shape of the Ka'ba's roof, the objects and decoration within the Meccan sanctuary may provide more hopeful starting points. It is indeed curious that before Muhammad's prophecy the local Meccans would have illustrated the Ka'ba with Jewish and Christian figures-that is, if we accept al-Azraqi's account. Vaziri observes: "It seems far-fetched that the pre-Islamic paintings of the Ka'ba, a shrine whose patrons before the Prophet of Islam were neither Christian nor Jewish, would have contained paintings of biblical characters. The nature of these paintings may have been the remainder of pre-Islamic Hindu-Buddhist art work, if any." (Vaziri 2012 , 94) Vaziri was not the first author to suggest this. A crucial figure here is Hāritī, a Buddhist goddess or demon who used to eat children, but upon her conversion to Buddhism became a protector of children. Ernest Binfield Havell (1861-1934), British administrator in India and art historian, argued in his Handbook of Indian Art that the painting of the Virgin Mary in the Ka'ba may in fact have shown Hāritī and her partner and that the two female characters were confused (Havell 1920, 106). According to Havell, who considered Islamic architecture unoriginal, the history of the mosque began with Buddhist temples. (Banerji 2002) The Ka'ba marked the starting-point of

15 As King points out, although this is not certain, Bāqūm may very well have been an Ethiopian, an assumption cited by Vaziri. Whoever exactly Bāqūm was, his Byzantine affiliation seems uncontroversial. 
this development: "the most venerated shrine in Arabia, which was the first model of a Muhammadan mosque, strongly suggests a Buddhist temple or monastery filled with Mahāyānist images". Havell argued that when the Buddhist images were removed from the temple, empty niches remained behind, and these were repurposed as mihrab indicating the direction of prayer. Extrapolating from later cases of Islamization of the built environment, he explained that in private homes such empty niches were used as "cupboards or receptacles for the hookah, rose-water vessel, lamp, or other articles of domestic use" (Havell 1920, 107).

The history of Hāritī worship may lend strength to the suggestion that a Hāritī statue ended up in western Arabia. The goddess was popular in Gandharan art and was especially associated with the protection of children from smallpox (Ahuja 2016). A.D.H. Bivar suggested a more specific reason for the flourishing of Hāritī representations in Gandharan art during the empire of the Kușānnas (second century BCE - third century $\mathrm{CE}$ ) in particular. He related the spread of the cult to the outbreak of the Antonine Plague in the Roman Empire in $165 \mathrm{CE}$, citing evidence from throughout the Asian continent, including southern Arabia and China. Assuming that the disease in question was smallpox and originated in South Asia, he proposed that "the epidemic was already growing in the reign of Kanișka. Within a few years the infection would have been reaching pandemic proportions, and the numerous Hāritī images of Gandhāra would thus reflect the growing desperation of the Buddhist devotees" (Bivar 1970, 21). The Kușānas are widely recognized as instrumental for the westward expansion of Buddhism. ${ }^{16}$ If Hāritī was especially popular during the Kușāna empire, it seems a little more plausible that a stray Hāritī statue or other representation may have ended up in western Arabia. Whether it served as a model for a Ka'ba painting is something else.

The theory of Hāritī in the Ka'ba requires a closer examination of the iconographic tradition in order to substantiate the possibility of a misidentification. Al-Azraqi cites his grandfather for more details. His grandfather transmits a report from Ibn Jurayj, who overheard an exchange between Sulaymān ibn Mūsā al-Shāmī and and 'Ațā' ibn Abī Rabāh. The former enquired, "Have you seen in the Ka'ba an image (timthāl) of Maryam/Mary and 'Īsā/Jesus," whereupon 'Ata' affirmed, "Yes, I have seen in the Ka'ba an image of the adorned Maryam with her adorned son "Īsā sitting in her lap" (AlAzraqī, [1403] 1983, I, 167; King 2004, 221, slightly modified). King identifies numerous parallels-Christian representations of the Virgin Mary with baby Jesus that match this description. The representations of Hāritī surveyed by Ahuja show the Buddhist goddess surrounded by about half a dozen children, mostly around her legs, which

16 For the Kuṣānas and the lasting significance of Greek and Hellenism see Halkias 2013. The Chinese pilgrim Xuanzang (ca. 596-664) also describes the worship of Hāritī in Gandhara. See Xuanzang 1884, 110-11. 
scarcely resembles the reported Ka'ba painting. Here we might note that a Hāritī closer to the iconography of the Virgin Mary with baby Jesus can be found on a Gandharan rondel in the collection of the Metropolitan Museum. A single child sits prominently on the lap of the lavishly adorned woman: it is one of the earliest Hāritīs and dates to the first century CE. The great historian of Gandharan Buddhist art, Alfred Foucher, demonstrated just how easily Hāritī can be associated, even confused with the Virgin Mary, when wrote about the "Buddhist Madonna", a label picked up by Havell (Havell 1920, 106; Foucher 1917, 271-91).

A second story has attracted the interest of modern proponents of Buddhist influences: the treasure of the Ka'ba. According to a tradition widely quoted in medieval Arabic literature, the Jurhum, the old custodians of the sanctuary, were defeated by another tribe, the Khuzā'a, and before the Jurhum left Mecca, they buried the treasure of the Ka'ba in the Zamzam well. Ibn Hishām (d. 218/834), editor of Ibn Isḥāq's (d. $151 / 768$ ) life of the prophet, an important text in the Islamic tradition, provides details regarding the treasure, which was later discovered by Muhammad's uncle 'Abd alMuțțalib. "He found in it two gazelles of gold. These were the two gazelles which the Jurhum had buried in the well when they left Mecca. He also found in it Qal'i swords and armor." (Wheeler 2006, 19) Of interest here are the two golden gazelles. While R.B. Serjeant and Brannon Wheeler put them in the contexts of the Arabian ritual hunt and animal sacrifices (Serjeant 1976, 88; Wheeler 2006, 26 and 152), ${ }^{17}$ the gazelles also bring to mind the Buddha's sermon at the deer park in Sarnath. As Mostafa Vaziri points out, two deer regularly appear in Buddhist art, where they frequently flank the wheel of dharma. One can see them, for example, in Gandharan schist panels (Behrendt 2007, 39 and 81).

Where does this take us? Not very far. Ruminating artiodactyla, such as various kinds of gazelles or deer, can be found all over the world and are widely represented in figurative art. Even the religious context for these animals is too general to serve as evidence for cultural influences. ${ }^{18}$ Another feature of these objects, which had allegedly been kept in the Ka'ba, might be helpful: their material. Gold is not a common material

17 See also Beeston 1948. The collection of poetry attributed to Ḥassān ibn Thābit, a contemporary of the prophet Muhammad, contains a related episode in which the material of the gazelle ( $g h a z a \bar{l})$ of the Ka'ba is identified as gold and its eyes as jewels (yāqūt). See ibn Thābit 1910, 51-7. The extent to which the material in this collection actually is Ḥassān's, however, is controversial.

18 For an example where no Indian influence can be claimed see the seventh-century Maya figurine of a deceased king who is accompanied by a deer as his way or spirit companion into the world of the dead (Grube and Schubert 2016, 88-9). For the way see also Looper 2012, 198. For deer in Maya art see Stone and Zender 2011, 184-5. 
of ancient Arabian objects, but any surviving separate golden or gilded representations of deer in Buddhist art date to the period after the rise of Islam. ${ }^{19}$

Gandharan art, however, may offer an avenue for an unsolved problem surrounding the Ka'ba paintings, which, as we saw earlier, are reported to have included an illustration of Ibrāhīm/Abraham and, according to a variant, Ismāiīl/Ishmael with divining arrows (King 2004, 223). Divining arrows are one of the few pre-Islamic Arabian rituals that are described in some detail in sources of the Islamic tradition and which are clearly rejected as a practice that should not continue. As King points out, no Christian iconographic parallels have been identified that would explain why Ibrāhīm or Ismā'īl would carry such arrows. Given the use of divining arrows in the pre-Islamic tradition, one might imagine a fusion of Christian iconography and Arabian practice. If we assumed, however, that Gandharan images were washed up in Mecca in one way or another and displayed in the Ka'ba, the image of Vajrapāni might offer a solution. The companion of the Buddha is often shown with a fly whisk and a thunderbolt known as vajra. The highly stylized thunderbolt may have been mistaken for a set of arrows, grasped tightly in the middle in the fist, the "arrows" diverging from each other at the respective ends.

More convincingly, King puts the brief literary descriptions of the paintings in the context of late antique Christian iconography. Given the consequences of Byzantine iconoclasm, the evidence that can serve comparative purposes is scant, especially in the case of Ibrāhīm and his divining arrows. However, King too concludes that Meccan trade must have been critical for the introduction of Christian iconography to the Ka'ba, especially "Palestine, Syria, Egypt, Yemen, and Ethiopia" (King 2004, 225). Illuminated manuscripts also may have served as a source. On the other hand, trade too could account for the presence of Indian objects in western Arabia. Furthermore, while the guardians of the Ka'ba in pre-Islamic times may not have been Christian, we have no indication that they were Buddhists, either, or followed any other Indian religious tradition. The same inclusiveness which would have allowed them to display an image of Hāritī in the Ka'ba would have allowed them to include an image of the Virgin Mary.

As tempting as it is to include pre-Islamic Mecca in ever new ways into the entangled religious landscapes of Eurasia, the theory of the Ka'ba as a Buddhist sanctuary relies on strained conjecture and forced and circumstantial evidence. There is no positive evidence which would point to a misidentification of Hāritī with the Virgin Mary, and the parallels between Buddhist and Muslim ritual are more easily explained as widespread

19 For bronze statues in Buddhist art manufactured before the emergence of Islam primarily in China and Korea see Leidy 2008, 55, 72, 84, 90, 102 and 105. I would like to thank Christian Luczanits for sharing his expertise on Buddhist art. 
human practices than as evidence of influence. Finally, the lack of visual sources puts us in a difficult position where we have to rely on textual evidence only.

On some level, this reconstruction of early Islamic history which stipulates Buddhist influences clearly presents a challenge to the Islamic tradition, which does not acknowledge such a presence of Indian or Buddhist religious objects in Mecca except as a legacy of remote history. To what extent the Islamic tradition is meant to be agent or reflection in the eradication of Buddhist testimonies remains unclear in the literature surveyed here. The most significant challenge may lie in the challenge to the relationship between Islam and other religions as established by historical events. The story about Muhammad and the painting of Mary and Jesus reflects and prefigures the general relationship between Islam and Christianity, as does Muhammad's smashing of the idols which paradigmatically defines the attitude to idolatry. The idols stand especially for Arabian idolatry and polytheism, a tradition which was meant to be entirely replaced by Islam. While authors like Ibn al-Kalbī may have been happy enough to see a connection in India in the remote past, a more recent connection may have implied that Meccan idolatry and polytheism were in fact not locally particular, but continued to exist in India, eventually even under Muslim rule. Maḥmūd of Ghazna may not have wanted to accept this, but Muslims must have been aware of ongoing Indian practices of using objects in religious worship, as travel reports indicate, for example.

On another level, the theory of Buddhist material culture in Mecca validates the Islamic tradition. It accepts the story of Muhammad smashing idols as a description of early seventh-century events. It does not re-read these idols as polemical representations of Christian objects along the lines of more radical revisionist reformulations. One may say that it presents a greater challenge to tradition than to Tradition, disputing the interpretation more than the text.

\section{Aisha and the Indian Physician}

Another piece of evidence adduced for Indian or Buddhist influences on early Islam is a brief Tradition about Muhammad's wife Aisha, who, according to reports, was treated by a physician of the Jats, who originated from India. Known in Arabic as Zuțt, the ancestors of these people had reportedly been moved to the Persian Gulf in Sasanian times, as early as two centuries before the emergence of Islam (Bosworth 2012; Morony 1984, 271-2; Wink 2002, 156-8). Although nobody seems to suggest that the Zuțt were Buddhists, ${ }^{20}$ their presence on the western shores of the Arabian Peninsula, in the Hijaz,

20 Manan Ahmed Asif quotes the historian al-Balādhurī (d. 279/892) as indicating in his Kitāb futūḥ al-buldān that an Umayyad official was killed by "the Jat people of the Buddhists" when he came 
would allow for the argument that the prophet Muhammad could indeed have had contact with Indians who may have retained their own religious traditions. The report about Aisha and the Zuțț physician is cited by Alexander Berzin, M.K. Agarwal, Karam Tej Sarao and the authors of numerous websites (Berzin n.d.; Agarwal 2012, II, 105; Sarao 2015). (A number of other websites where such a story is reported can be easily found with keywords such as "Kaaba" and "Vedic".) What appears to be the source of this story among modern authors can be found in al-Bukhārī's (d. 256/870) collection of hadiths about Muslim manners, al-Adab al-mufrad, where it is listed in the chapter on "selling a slave from the Arabs". The full text is as follows:

I was told by Sulaymān ibn Ḥarb on the authority of Ḥammād ibn Zayd on the authority of Yahyyā ibn Sa'īd on the authority of Ibn 'Amara on the authority of 'Amara. Aisha-may God be pleased with her-manumitted (dabbarat) a female slave [who was going to be free after Aisha's death]. Aisha then began to complain of an illness and her nephew consulted a doctor (țabib) who belonged to the Zuttt. The doctor told him, 'You have described a bewitched (mashūra) woman who was bewitched by a female slave of hers'. Aisha was informed about this and asked, 'Did you bewitch me?' The female slave responded, 'Yes.' Aisha enquired, 'But why? You are never going to be saved.' Then she said, 'Sell her to the worst slaveholders among the Arabs!' (al-Bukhārī [1421] 2000, 65-6) ${ }^{21}$

Berzin and other authors cite the report as evidence that Muhammad was familiar with Indian culture. Others recognize a sign of respect for Indian learning. Like any historical source, however, it requires critical scrutiny, for the story about Aisha's Indian physician is anything but straightforward. As already discussed, the Islamic tradition preserves a great wealth of information about the earliest days of the religion's history, the life of the prophet Muhammad, his family and companions. Accordingly, in 1851, Ernest

to the rescue of Muslim women who were sent back from Sri Lanka and abducted on the way. See Asif 2016, 37, with reference to the Arabic text as Futūh al-buldān (Beirut, 1988), 419-420. In subsequent historical writing, the incident accounts for the Muslim invasion of Sind. This would make al-Balādhurī a notable exception. The Arabic text, however, does not appear to warrant this reading. Francis Clark Murgotten renders it as "he was killed by the Zuțț of al-Budhah" (Al-Balādhurī 1924, 216). "Al-Budhah", however, would be an uncommon version of the Arabic word al-budd, which is used to refer to statues of the Buddha. Moreover, as the edition by de Goeje reveals, the reading is far from certain. Variants suggest that copyists were not familiar with the term. Apart from uncertainties about the short vowels, the character dāl has also be read as rā', which has led to the identification of the group with the tribe "Burhoee" or "Buroohee". See Al-Balādhurī 1866, 436.

21 Hadīth 162 in the collection. Read man sharr al-'arab malakatan instead of min sharr al-'arab malakatan. Most scholars seem to consider the hadīth sound (șahịh). 
Renan declared confidently that Islam had emerged in the "full light of history" (Renan $1851,1065)$. The historical reliability of these sources, however, has now come under great scrutiny as part of revisionist critique. Hadith and sira (prophetic biography) are increasingly analyzed as products of eighth- and ninth-century religious and political thought, rather than repositories of early seventh-century traditions. As such, they reflect the religious, political and cultural concerns of the time in which they were compiled, although these are in some cases more obvious than in others.

What then of al-Bukhārī's hadīth about Aisha and her Indian physician? First of all, Muḥammad al-Bukhārī hailed from eastern Iran and spent most of his life there, although as a young man he went to the Hijaz on pilgrimage. He was born in 194/810 and thus lived more than two centuries after Muhammad. Even though al-Bukhārī is famed for his brilliant memory, the chronological and geographical distance to early seventh-century western Arabia alone should raise doubt concerning his reliability as a source for that history-rather than his own. Disciplines of oral and written transmission can be traced into the eighth century, but not back to the early seventh.

Was there, then, any reason for al-Bukhārī to invent the story about Aisha and the Zutt physician? Indeed, what is the point of the story and its significance in the tradition? It does not seem to be the physician who merely diagnoses Aisha's illness as bewitchment. The point rather seems to be the status of the slave. More specifically, her condition is deferred manumission (tadbir), which occurred upon the owner's death (Goldziher 2008, 82-3; Brockopp 2000, 115-205). In legal terminology, such a slave is accordingly called a mudabbar. Aisha's female mudabbar slave apparently sought to expedite her manumission by killing her owner through magical means. Aisha, also reported elsewhere as having manumitted slaves, decides to punish her would-be murderer by selling her to a harsh slaveholder. It is this point which was of interest to the legal scholars and thus explains the rationale of the Tradition. Can a slave whose manumission has already been decided still be sold? And what of a slave who attempts to speed up the procedure, does that void the tadbir? The Syrian Hanbali scholar Ibn Qayyim al-Jawziyya (691/1292-751/1350) affirmed this, although it was only the modern editor who referred to the Aisha story in al-Adab al-mufrad as a parallel (Ibn Qayyim al-Jawziyya 1999, 610). In premodern Arabic literature, the hadith does not seem to appear very frequently.

Interestingly, variations of the same story appear in other collections of Traditions, but the specific identification of the physician as a member of the Zuțt seems particular to al-Bukhārī. Two other collections of hadīths will be discussed here in order to illustrate the complexity of the issue. A generation before al-Bukhārī, Aḥmad ibn Hanbal (164/780-241/855), the eponym of the Hanbali school of law, compiled his own selection of hadiths in his Musnad. Although Ahmad's family had a connection with 
Khurasan, he was born and spent most of his life in Iraq (Melchert 2013). In Ahmad's version, the story is as follows:

Sufyān told us on the authority of Yaḥyā on the authority of Ibn Akhī (i.e., the nephew of) 'Amra-I don't know this one or the other one-on the authority of 'Amra. She said:

Aisha was suffering an illness and the illness prolonged. A man who practiced medicine came to Medina, and her nephew sought him out in order to ask him about her ailment. He said, 'By God, you offer the description of a woman who has been bewitched (mațbūba).' He [the nephew?] said, 'This is a bewitched woman who has been bewitched by a female slave of hers.' She [the slave] said, 'Yes, I wanted you to die so that I will be freed.' He explained, 'She was a mudabbar.' She [Aisha] said, 'Sell her to the worst slaveholders among the Arabs and set her price accordingly!' (Ibn Ḥanbal [1421] 2001, $154=6 / 40$ )

This version of the tradition confirms that the point of the story is the condition of the mudabbar slave rather than the identity of the physician. In Ahmad's variant, the physician comes from outside of Medina, but no details about his provenance are provided. The Indian connection is thus marginal, as far as the perspective of the Tradition is concerned.

Given that Aḥmad lived a generation before al-Bukhārī, it is reasonable to speculate that the later scholar changed some of the terms (such as mațbūba to mashūra, more unambiguously evoking magic) and added the detail about the physician's identity. The association between magic and India became common in Islamic literature (Zadeh 2014, 136 and 149). One may surmise that the Indian connection was added when India had become synonymous with magic and Arabia had receded into a background.

The third source is the earliest collection of hadith, the Muwațta' of Mālik ibn Anas, eponym of the Maliki school of law. Mālik died in 179/796 in his mid- to late eighties in Medina, which was the center of his life. Unfortunately for our purposes, the transmission history of his Muwațta' is very complicated. The text is preserved in several recensions that differ significantly, as Jonathan Brockopp points out: "An examination of six of the published versions of the Muwatța' reveals the very wide discrepancies which would be expected for a text that developed organically. Two of these recensions, those by al-Šaybānī and Ibn Wahb, differ so drastically from the vulgate recension of Yaḥyā b. Yaḥyā al-Layțī that they might be considered entirely different texts" (Brockopp 2000, 74; Wymann-Landgraf 2013, 60-63). Among the three recensions consulted for this article, those by al-Shaybānī (d. 189/805) and Abū Muș'ab 
al-Zuhrī (150/767-242/856) contain the story about Aisha and the Indian (here: Sindī) physician, whereas the most widely spread recension of the Muwațța', which is Yahyā's (d. 234/848), does not. This is not the place to delve into the intricacies of the history of the Muwațta'. Suffice it to say that the story about Aisha and the Indian physician was indeed older than al-Bukhārī, since it appears in Abū Muș'ab al-Zuhrī's recension, although his contemporary Ahmad did not include it in his own collection of hadiths. Given the discrepancies between the recensions, we cannot assume that the inclusion of the story dates back to Mālik ibn Anas himself.

It is worth noting that the version of the story in the two recensions of the Muwatța' consulted for this article differs from what we can find in al-Adab al-mufrad. The following is attributed to Mālik by al-Shaybānī and Abū Muș'ab:

Abū Muș'ab reported to us on the authority of Mālik on the authority of Abū al-Rijāl Muhammad ibn 'Abd al-Raḥmān on the authority of his mother 'Amra about Aisha, may God be pleased with her. Aisha undertook to manumit a female slave who would gain her freedom after Aisha's death. Then, Aisha became ill as God willed. An Indian (Sindī) visited her and told her that she had been bewitched (mațbüba). She enquired, 'And who bewitched me?' He responded, 'A woman who is so-and-so,' and added that 'in her lap is a boy who has just urinated'. Aisha said, 'Get me the so-and-so', who was a slave of hers who served her. They found her in the house of her neighbors with a boy in her lap who had just urinated. Aisha commanded that she should wash away the urine of that boy, and the woman cleaned herself and came to Aisha. Aisha asked her, 'Did you bewitch me?' She responded, 'Yes.' Aisha enquired, 'And why?' The woman answered, 'Because I want to be freed.' Aisha said, 'You wanted to be freed, but by God, you will never be freed!' Aisha instructed her nephew to sell her to the worst slaveholder among the Arabs and said: 'And then use the money from the sale to purchase a slave girl so that I may free her.' He followed her instructions. (Ibn Anas [1412] 1991, part 2, 422, n. 2782) 22

In this version, the element of magic is enhanced even further: the Indian doctor has information about facts beyond his sense perception. In order to analyze this story more fully, the prominent presence of magic and its association with India would need to be taken into account. Either way, the story does not hold up as evidence for Muhammad's familiarity with Buddhism or India in general. Here again, modern authors affirm Tradition while challenging tradition. The hadith is evoked without any 
source criticism and used in order to make a larger case for an Indian presence not acknowledged by the tradition.

An obvious challenge to theories about Buddhist influences on early Islam is that such a Buddhist presence has left no discernible trace in the Qur'an. Markus Groß has argued that surah 109 betrays Buddhist influences, but he relies on a re-reading of the Arabic text as well as on a very general structural argument (Groß 2009, 355-73). There are, to be sure, a number of attempts especially in the context of interreligious dialogue to demonstrate that Qur'anic and Buddhist values are compatible or even identical. This, however, is very different from a historical argument that stipulates a Buddhist influence on Muhammad or on the Qur'an. The most prominent theory was presented by Hāamid 'Abd al-Qādir in his The Life and Philosophy of the Buddha, a book frequently mentioned but hardly ever cited. ${ }^{23}$ The author is adduced to suggest that the Qur'anic character Dhū 'I-Kifl is actually the Buddha, the name reflecting his birthplace Kapilavastu, a view expressed by others as well, such as Mirza Tahir Ahmad (1926-2003), leader of the Ahmadiyya (Ahmad 2010, 24; Siddiqi 1970, 586). While the origins of this figure remain controversial, there is no indication other than the popular etymology that Dhū 'I-Kifl might be inspired by an Indian tradition. Most theories revolve around Jewish and Biblical roots. In a less controversial area, W.H. Siddiqi lists words of Indian origin in the Qur'an. These reflect, in all likelihood, a history of trade relations but are unrelated to religion or Buddhism.

While most modern scholars will find such etymologies unpersuasive, M.K. Agarwal invokes an authority which lends these explanations greater weight than they might usually be credited with: "Al-Biruni has noted that the Arabs changed Sanskrit names into Arabic to camouflage the real origin" (Agarwal 2012, I, 3). Elsewhere, the author elaborates: "To usurp non-Greek knowledge, Greek sounding names were invented by Latin translators of Arabic texts just as Sanskrit names were changed into Arabic by Arabs who had manipulated Sanskrit names. Al-Biruni notes that the name Aryabhata was changed to Arjbhad and later to Azjabhar (al-jabbar) so 'Hindus will not recognize it'" (Agarwal 2012, I, 496; Agarwal 2013, 309). The passage in question can be found in al-Bīrūnī's famous book on India, but it hardly bears out the implication of deliberate disfiguration of Indian origins. In Sachau's translation, the medieval author makes the following observation:

23 At least in North America, it is virtually impossible to obtain access to a copy. The two copies listed in WorldCat are non-circulating and can be found at the Library of Congress and at McGill. None of the literature I have consulted for this article cites the actual book with a page number, mentions any evidence presented in the book or evaluates theories or sources. 
We meet in this context with a curious circumstance. Evidently Alfazârî and Ya'kûub sometimes heard from their Hindu masters expressions to this effect, that his calculation of the star-cycles was that of the great Siddhânta, whilst Âryabhața reckoned with one-thousandth part of it. They apparently did not understand him properly, and imagined that âryabhata (Arab. ârjabhad) meant a thousandth part. The Hindus pronounce the $d$ of this word something between a $d$ and an $r$. So the consonant became changed to an $r$, and people wrote ârjabhar. Afterwards it was still more mutilated, the first $r$ being changed to a $z$, and so people wrote âzjabhar. If the word in this garb wanders back to the Hindus, they will not recognise it. (AlBīrūnī 1910, II, 18-19)

Seizing this as carte blanche, Agarwal and other authors present a wide range of Arabic etymologies that are meant to reflect Indian origins. The name of the month Ramadan, for example, is allegedly derived from the Indian deity Rama. (The examples and details can be established with the help of a search engine.)

\section{Muslim-Buddhist Contacts in the Formative Period}

No matter how present Buddhist elements may have been in the Middle East and Arabia at the eve of Islam and during the period of the religion's emergence, there is little doubt that during the formative period of Islamic history Muslims became more exposed to Buddhism and gained greater knowledge of this tradition. Daniel Gimaret's article of 1969 still serves as a useful survey on the subject (Gimaret 1969).

To mention but some of the most prominent cases, the Fihrist, the thematic catalogue of books compiled by Ibn al-Nadim in the tenth century in Iraq, includes a number of relevant details, such as the book of Bilawhar wa-Būdhāsaf (Ibn al-Nadìm 1970, I, 260), about which more below, and various references to Buddhism in the sections on India and China (Ibn al-Nadīm 1970, II, 826-42). In the ninth chapter, he describes several objects and practices of worship in India and China as well as several beliefs, among them those of the Shamaniyya (see al-Bīrūnī above). This group, also known as Sumaniyya, is associated in various ways with Buddhism, although a discussion of the Sumaniyya is beyond the scope of this article (Gimaret 1969, 288-306; Crone 2012; Monnot 2012). The Sumaniyya as well as the Barāhima, likewise connected to India, entered the orbit of Islamic philosophy, theology and even legal sciences as deniers of prophecy. They are also said to have denied that multiple separate transmissions (tawātur) furnished certainty in the realm of law (Zysow 2013, 13). Likewise, a group known as the Dahriyya is associated both with such views and with India, although the 
latter connection is very tenuous (Crone 2010). While the circumstances under which these groups appeared in Islamic literature in these particular forms are well outside the scope of this article, their presence is indicative of considerably closer connections to India in the formative period of Islam than during Muhammad's time. None of these groups is mentioned in the Qur'an. Any assumption of familiarity with these groups on the part of the earliest Muslims betrays back-projection.

Another important Buddhist contribution to Islamic and Islamicate culture is a text mentioned earlier in the Fihrist, where Ibn al-Nadim lists a book with the title Bilawhar wa-Būdhāsaf. This is the Arabic title of a version of the life of the Buddha which enjoyed great popularity in different languages of medieval western Eurasia (Gimaret 1971a, 1971b and 1972; Stern and Walzer 1971; De Blois 1990, 34-7; ToralNiehoff 2000-2001; Lopez and McCracken 2014). The story of the Buddha, whether through the book of Bilawhar and Būdhāsaf or otherwise, is sometimes claimed to have left a trace in the Sufi tradition, namely in the story of Ibrāhīm ibn Adham (d. 166/782) (Jones 2012; Tsugitaka 2007). Like Siddhartha Gautama, Ibrāhīm is reported to have been born as a prince, but then sought the life of an ascetic. In traditions about this early renunciant, Ibrāhīm encounters a mysterious man by the name of Khiḍr, a sort of immortal prophet especially popular in the Sufi tradition. Khidur too is associated with the Buddha in traditions independent of Ibrāhīm ibn Adham (Franke 2000, 58; Vaziri 2012, 73-5; Yusuf 2010, 118-19). Al-Shahrastānī (d. 548/1153), for instance, stated that in the Islamic tradition only Khidur compared to the Buddha (Lawrence 1976, 43 and 113-14). The similarities between early Muslim and Buddhist renunciants are such that they have given rise to theories about Buddhist or Indian origins of Sufism. Even if individual Muslim renunciant movements were inspired or influenced by Buddhist traditions, however, the origins of Muslim asceticism are certainly more complex. The same applies to theories that attribute the canonization of hadiths to similar Buddhist tendencies (Groß 2009, 375-82). ${ }^{24}$

\section{Conclusions}

Whenever historians approach sources which play an important role in the salvation history of a particular religion, certain concerns are regularly part of their analytical tool box. One of them involves entanglements of this particular religion with other religions. Historical narratives of a religious tradition might downplay the significance

24 Starr also suggests an influence of the religious milieu of Central Asia, including Buddhism, on the canonization of hadith. See Starr 2013, 247. For comparisons between Islamic and Buddhist developments see Cook 1997 and Brown 2009, 272-3. 
of another religion or even edit it out in order to enhance claims of originality and superhuman validation. On the other hand, the presence or significance of another religion might be exaggerated, for example in order to indeed downplay that of another religion, or in order to emphasize certain features of one's own religion-monotheism in a polytheistic environment, for example.

As interest in cultural contacts and connected histories has grown, so has the awareness that no religion emerges in a vacuum. However, representations of the religious, cultural, social and political environment in which a given religion emerged usually reflect doctrinal tendencies that develop in subsequent years. This is as true of Islam as of any other religion. Among modern authors, views concerning the "sectarian milieu" in which Islam emerged differ widely, as mentioned above. While some historians basically accept the premises of the Islamic tradition and locate Muhammad's prophetic mission in a polytheistic environment in which idolatry was part of religious practice, others understand the polemics against "associators" as a trope of intra-monotheistic discourse. The views surveyed in this article occupy a curious position in this field. On the one hand, they present a significant challenge to conventional narratives of the religious landscape in which Islam emerged. One might call this the challenge to the Islamic tradition. On the other hand, many of the authors who argue in favor of a Buddhist or Indian presence are fairly moderate in their source criticism. While occasionally challenging the interpretation of reports, they often take the general reliability of the Tradition's historical accounts for granted and thus validate this body of textual sources.

While this survey has not found that theories of Buddhist presence and influence are more or even as plausible as other representations of pre- and early Islamic Mecca, this does not mean that these parallels, connections and crosspollinations were insignificant in subsequent periods of Islamic history, when the religion spread into historically Buddhist territories. Just how much the memory of the material presence of Buddhism, or Indian religions in general, informed Islam is obvious from early modern Turco-Persian paintings that depict Muhammad and his companions destroying idols in the Ka'ba. The Meccan idols are reminiscent of statues of the Buddha (Elverskog 2010, 63-7 and 117-74; Gruber 2018). This is but one example of the common practice of back-projecting, a practice which is sometimes more compelling than the narratives it produces. 


\section{References}

Agarwal, Manjul K. 2012. From Bharata to India. 2 volumes. Bloomington: iUniverse. - - - 2013. The Vedic Core of Human History. Bloomington: iUniverse.

Ahmad, Mirza Tahir. 2010. An Elementary Study of Islam. Tilford: Islam international. Ahuja, Naman P. 2016. "The British Museum Hāritī: Toward Understanding Transculturalism in Gandhara." In Beyond Boundaries: Connecting Visual Cultures in the Provinces of Ancient Rome, edited by Susan E. Alcock, Mariana Egri, and James F.D. Frakes, 247-63. Los Angeles: Getty Publications.

Akasoy, Anna. 2012. "Paganism and Islam. Medieval Arabic Literature on Religions in West Africa." In Paganism in the Middle Ages: Threat and Fascination, edited by John Marenbon, Carlos Steel, and Werner Verbeke, 207-38. Leuven: Leuven University Press.

- - - 2013. "The Buddha and the Straight Path. Rashīd al-Dīn's Life of the Buddha: Islamic Perspectives." In Rashìd al-Dìn, Agent and Mediator of Cultural Exchanges in IIkhanid Iran, edited by Anna Akasoy, Charles Burnett, and Ronit Yoeli-Tlalim, 173-96. Warburg Institute Colloquia, vol. 24. London: The Warburg Institute.

-_- 2016. "Geography, History and Prophecy: Mechanisms of Integration in the Islamic Alexander Legend." In Locating Religions: Contact, Diversity and Translocality, edited by Nikolas Jaspert and Reinhold Glei, 16-36. Leiden: Brill.

Asif, Manan Ahmed. 2016. A Book of Conquest: The Chachnama and Muslim Origins in South Asia. Cambridge, MA: Harvard University Press.

Al-Azraqī. (1403) 1983. Akhbār Makka [History of Mecca]. Edited by Rushdī al-Ṣāliḥ Malḥas, third edition. Beirut: Dār al-Andalus.

Al-Balādhurī. 1866. Liber expugnationis regionum [Book of the Conquest of Lands]. Edited by M.J. de Goeje. Leiden: Brill.

- - . 1924. The Origins of the Islamic State, being a Translation from the Arabic, Accompanied with Annotations, Geographic and Historic Notes of the Kitâb futûh al-buldân of al-Imâm abu-l Abbâs Aḥmad ibn-Jâbir al-Balâdhuri. Volume

2. Translated by Francis Clark Murgotten. New York: Columbia University.

Banerji, Debashish. 2002. "The Orientalism of E B Havell." Third Text 16 (1): 41-56.

Beeston, A.F.L. 1948. "The Ritual Hunt. A Study in Old South Arabian Religious Practice." Le Muséon 61: 183-96.

Begley, Vimala, and Richard Daniel de Puma, eds. 1991. Rome and India: The Ancient Sea Trade. Madison: University of Wisconsin Press.

Behrendt, Kurt A. 2007. The Art of Gandhara in the Metropolitan Museum of Art. New York: Metropolitan Museum of Art. 
Berzin, Alexander. n.d. "First Encounter of the Muslims and Buddhist Asia." Last accessed January 21, 2019. https://studybuddhism.com/en/advanced-studies/ history-culture/buddhism-islam-advanced/buddhist-muslim-interactionumayyad-caliphate/first-encounter-of-the-muslims-and-buddhist-asia.

-_- . 2010. "Historical Survey of the Buddhist and Muslim Worlds' Knowledge of Each Other's Customs and Teachings." The Muslim World 100 (2-3): 187-203.

Al-Bīrūnī. 1910. Alberuni's India: An Account of the Religion, Philosophy, Literature, Geography, Chronology, Astronomy, Customs, Laws and Astrology of India about A.D. 1030. Translated by Edward C. Sachau. London: Kegan Paul, Trench and Trübner.

Bivar, A.D.H. 1970. "Hāritī and the Chronology of the Kuṣāṇas." Bulletin of the School of Oriental and African Studies 33 (1): 10-21.

Blair, Sheila. 1995. A Compendium of Chronicles: Rashìd al-Dīn's Illustrated History of the World. London: Azimuth Editions and Oxford University Press.

Bosworth, C. Edmund. 1994. "Abū Ḥafș 'Umar al-Kirmānī and the Rise of the Barmakids." Bulletin of the School of Oriental and African Studies 57 (2): 268-62.

- - - 2012. "Al-Zuțț." In Encyclopaedia of Islam, Second Edition, edited by Peri Bearman et al. Online edition. Leiden: Brill.

Brockopp, Jonathan E. 2000. Early Mālikì Law: Ibn 'Abd al-Hakam and his Major Compendium of Jurisprudence. Boston: Brill.

Brown, Jonathan A.C. 2009. Hadith: Muhammad's Legacy in the Medieval and Modern World. Oxford: Oneworld.

Buhl, F. 2012. "Ṭawāf." In Encyclopaedia of Islam, Second Edition, edited by Peri Bearman et al. Online edition. Leiden: Brill.

Al-Bukhārī. (1421) 2000. Al-Adab al-Mufrad [The Singled Out Manners]. Edited by Abū 'Abdallāh Muhammad Nāṣir al-Dīn al-Albānī. Third edition. Beirut: Dār al-Șadīq.

Casson, Lionel. 1989. "Southern Arabia's Maritime Trade in the First Century A.D." In L'Arabie préislamique et son environment historique et culturel, edited by T. Fahd, 187-94. Leiden: Brill.

Chakravarti, Ranabir, ed. 2001. Trade in Early India. Delhi: Oxford University Press.

Cook, Michael. 1997. "The Opponents of the Writing of Tradition in Early Islam." Arabica 44 (4): 437-530.

Corpus of South Arabian Inscriptions. Last accessed January 21, 2019. http://dasi. humnet.unipi.it/index.php?id=42\&prjld $=1 \&$ corld $=0 \&$ colld $=0$.

Crone, Patricia, and Martin Hinds. 1986. God's Caliph: Religious Authority in the First Centuries of Islam. Cambridge: Cambridge University Press.

Crone, Patricia. 1987. Meccan Trade and the Rise of Islam. Princeton: Princeton University Press. 
-_-. 2010. "The Dahrīs According to al-Jāḥiż." Mélanges de I'Université Saint-Joseph 63: 63-82.

- - . 2012. "Buddhism as Ancient Iranian Paganism." In Late Antiquity: Eastern Perspectives, edited by Teresa Bernheimer and Adam Silverstein, 25-41. Warminster: Gibb Memorial Trust. [Reprinted in Crone, Patricia. 2016. The Iranian Reception of Islam: The Non-Traditionalist Strands, 212-32. Leiden: Brill.] Davis, Richard H. 1999. Lives of Indian Images. Princeton: Princeton University Press.

De Blois, François. 1990. Burzōy's Voyage to India and the Origin of the Book of Kalīlah wa Dimnah. London: Routledge.

Eck, Diana L. 2005. "Circumambulation." In Encyclopedia of Religion, second edition, edited by Lindsay Jones vol. 3, 1795-8. Detroit: Macmillan.

Elverskog, Johan. 2010. Buddhism and Islam on the Silk Road. Philadelphia: University of Pennsylvania Press.

Foucher, Alfred. 1917. The Beginnings of Buddhist Art and Other Essays in Indian and Central-Asian Archaeology. Paris: Geuthner.

Franke, Patrick. 2000. Begegnung mit Khidr: Quellenstudien zum Imaginären im traditionellen Islam. Beirut: Ergon.

Friedmann, Yohanan. 1975. "Medieval Muslim Views of Indian Religions." Journal of the American Oriental Society 95 (2): 214-21.

- - . 1998. "Classification of Unbelievers in Sunnī Muslim Law and Tradition." Jerusalem Studies of Arabic and Islam 22: 163-95.

Gardīzī. 2011. The Ornament of Histories: A History of the Eastern Islamic Lands, AD 650-1041. The Original Text of Abū Sa'īd 'Abd al-Hayy Gardīzī. Translated by C. Edmund Bosworth: New York: I.B. Tauris.

Gimaret, Daniel. 1969. "Bouddha et les Bouddhistes dans la tradition musulmane." Journal Asiatique 257: 273-316.

-_-, ed. 1971a. Le livre de Bilawhar et Būdāsf selon la version arabe ismaélienne. Geneva: Droz.

- - . 1971b. "Traces et paralleles du Kitāb Bilawhar wa Būdāsf dans la tradition arabe." Bulletin d'études orientales 24: 97-133.

-—-, ed. 1972. Kitāb Bilawhar wa-Būd̄āsf. Beirut: Dar el-Machreq.

Goldziher, Ignaz. 2008. The Zāhirīs: Their Doctrine and their History. A Contribution to the History of Islamic Theology. Translated and edited by Wolfgang Behn. Leiden: Brill.

Groß, Markus. 2008. "Buddhistische Einflüsse im frühen Islam?" In Schlaglichter: Die beiden ersten islamischen Jahrhunderte, edited by Markus Groß and Karl-Heinz Ohlig, 220-74. Berlin: Hans Schiler. 
- - . 2009. "Frühislam und Buddhismus. Neue Indizien." In Vom Koran zum Islam, edited by Markus Groß and Karl-Heinz Ohlig, 347-96. Berlin: Hans Schiler.

Grube, Nikolai, and Alexander Schubert. 2016. Maya: Das Rätsel der Königsstädte. Munich: Hirmer.

Gruber, Christiane. 2018. "In Defense and Devotion. Affective Practices in Early Modern Turco-Persian Manuscript Paintings." In Affect, Emotion, and Subjectivity in Early Modern Muslim Empires: New Studies in Ottoman, Safavid, and Mughal Art and Culture, edited by Kishwar Rizvi, 95-123. Leiden: Brill.

Halkias, Georgios. 2013. "When the Greeks Converted the Buddha. Asymmetrical Transfers of Knowledge in Indo-Greek Cultures." In Religions and Trade: Religious Formation, Transformation and Cross-Cultural Exchange between East and West, edited by Peter Wick and Volker Rabens, 65-115. Leiden: Brill. Havell, Ernest B. 1920. A Handbook of Indian Art. London: John Murray.

Hawting, G.R. 1984. "The Origin of Jedda and the Problem of al-Shu'ayba." Arabica 31 (3): 318-26.

Ibn Anas, Mālik. (1412) 1991. Al-Muwațța': Riwāyat Abī Muṣ‘ab al-Zuhrī al-Madanī. Edited by Bashshār 'Awwād Ma'rūf and Maḥmūd Muḥammad Khalīl. Beirut: Mu’assasat al-Risāla.

-_-. (1414) 1994. Muwațța' al-Imām Mālik: Riwāyat Muḥammad ibn al-Ḥasan alShaybānī. Edited by 'Abd al-Wahhāb 'Abd al-Lațīf, fourth edition. Cairo: Wizārat al-awqāf.

Ibn Ḥanbal, Aḥmad. (1421) 2001. Musnad. Edited by Shu'ayb al-Arna'ūț et al, volume 40. Beirut: Mu'assasat al-Risāla.

Ibn al-Kalbī. 1952. Book of Idols, Being a Translation from the Arabic of the Kitāb alAșnām. Translated by Nabih Amin Faris. Princeton: Princeton University Press. (Ibn) Al-Nadīm. 1970. The Fihrist of al-Nadìm: A Tenth-Century Survey of Muslim Culture. Translated by Bayard Dodge. New York: Columbia University Press. Ibn Qayyim al-Jawziyya. 1999. Ighāthat al-lahfān fĩ mașāyid al-shayțān [Help for the Worried from the Snares of the Devil]. Edited by 'Alī Ḥasan 'Alī 'Abd al-Ḥamīd. Dār 'ālam al-fawā'id.

Ibn Thābit, Ḥassān. 1910. The Dīwān of Hassān b. Thābit (ob. A.H. 54). Edited by Hartwig Hirschfeld. Leiden: Brill.

Jahn, Karl. 1965. Rashìd al-Dïn's History of India: Collected Essays with Facsimiles and India. The Hague: Mouton.

_-_. 1980. Die Indiengeschichte des Rašíd ad-Dīn. Vienna: Verlag der österreichischen Akademie der Wissenschaften.

Jones, Russell. 2012. "Ibrāhīm b. Adham." In Encyclopaedia of Islam, Second Edition, edited by Peri Bearman et al. Online edition. Leiden: Brill. 
King, Geoffrey. 1980. "Some Christian Wall-Mosaics in Pre-Islamic Arabia." Proceedings of the $12^{\text {th }}$ Seminar for Arabian Studies 10: 37-43.

- - . 2002a. "The Prophet Muhammad and the Breaking of the Jahiliyyah Idols." In Studies on Arabia in Honour of Professor G. Rex Smith, edited by John F. Healey and Venetia Porter, 91-122. Oxford: Oxford University Press.

- - . 2002b. "The Sculptures of the Pre-Islamic Haram at Makka." In Cairo to Kabul: Afghan and Islamic Studies Presented to Ralph Pinder-Wilson, edited by Warwick Ball and Leonard Harrow, 144-50. London: Melisende.

King, G.R.D. 2004. "The Paintings of the Pre-Islamic Ka'ba." Muqarnas 21: 219-29. Lawrence, Bruce B. 1976. Shahrastānī on the Indian Religions. Berlin: De Gruyter.

Leidy, Denise Patry. 2008. The Art of Buddhism: An Introduction to its History and Meaning. Boston: Shambala

Looper, Matthew. 2012. "The Maya "Cosmic Monster" as a Political and Religious Symbol." In The Ashgate Research Companion to Monsters and the Monstrous, edited by Asa Simon Mittman and Peter J. Dendle, 197-215. Farnham: Ashgate.

Lopez Jr., Donald S., and Peggy McCracken. 2014. In Search of the Christian Buddha: How an Asian Sage Became a Medieval Saint. New York: W.W. Norton \& Company.

Melchert, Christopher. 2013. Ahmad ibn Hanbal. Oxford: Oneworld.

Melikian-Chirvani, A.S. 1984. "The Buddhist Ritual in the Literature of Early Islamic Iran." In South Asian Archaeology 1981, edited by Bridget Allchin, 272-9. Cambridge: Cambridge University Press.

Monnot, Guy. 2012. "Sumaniyya." In Encyclopaedia of Islam, Second Edition, edited by Peri Bearman et al. Online edition. Leiden: Brill.

Morony, Michael G. 1984. Iraq after the Muslim Conquest. Princeton: Princeton University Press.

Parekh, Kulsum. 1954. "Some Controversial Points in the History of the Temple of Somnath." Islamic Culture 28: 287-96.

Parker, Grant. 2002. “Ex Oriente Luxuria. Indian Commodities and Roman Experience." Journal of the Economic and Social History of the Orient 45 (1): 40-95.

Power, Timothy. 2012. The Red Sea from Byzantium to the Caliphate: AD 500-1000. Cairo: The American University in Cairo Press.

Reade, Julian, ed. 1996. The Indian Ocean in Antiquity. London: Kegan Paul.

Renan, Ernest. 1851. "Mahomet et les origins de l'islamisme." Revue des deux Mondes December: 1063-1101.

Robinson, Chase F. 2010. "The Rise of Islam, 600-705." In The New Cambridge History of Islam, vol. 1: The Formation of the Islamic World, Sixth to Eleventh Centuries, edited by Chase F. Robinson, 171-225. Cambridge: Cambridge University Press. 
Sarao, Karam Tej. 2015. "Buddhist-Muslim Encounter in Sind during the Eighth Century." Accessed January 21, 2019. https://www.researchgate.net/ publication/305045170_Buddhist-Muslim_Encounter_in_Sind_during_the_ Eighth_Century.

Seland, Eivind Heldaas. 2017. "The Archaeological Record of Indian Ocean Engagements in the Red Sea." In Oxford Handbooks Online. Accessed January 21, 2019. http:// www.oxfordhandbooks.com/view/10.1093/oxfordhb/9780199935413.001.0001/ oxfordhb-9780199935413-e-51.

Seldeslachts, Erik. 1997. "Greece, the Final Frontier? The Westward Spread of Buddhism." In The Spread of Buddhism, edited by Ann Heirman and Stephan Peter Bumbacher, 131-66. Leiden: Brill.

Serjeant, R.B. 1976. South Arabian Hunt. London: Luzac.

Shokoohy, Mehrdad. 2012. "The Legacy of Islam in Somnath." Bulletin of the School of Oriental and African Studies 75 (2): 297-335.

Siddiqi, W.H. 1970. "India's Contribution to Arab Civilization." In India's Contribution to World Thought and Culture, edited by L. Chandra, 579-88. Madras: Vivekananda Rock Memorial Committee.

Sidebotham, Steven E. 1989. "Ports of the Red Sea and the Arabia-India Trade." In L'Arabie préislamique et son environment historique et culturel, edited by $\mathrm{T}$. Fahd, 95-223. Leiden: Brill.

Starr, S. Frederick. 2013. Lost Enlightenment: Central Asia's Golden Age from the Arab Conquest to Tamerlane. Princeton: Princeton University Press.

Stern, S. M., and Sofie Walzer, ed. and trans. 1971. Three Unknown Buddhist Stories in an Arabic Version. Oxford: Cassirer.

Stone, Andrea Joyce, and Marc Zender. 2011. Reading Maya Art: A Hieroglyphic Guide to Ancient Maya Painting and Sculpture. New York: Thames and Hudson.

Toral-Niehoff, Isabel. 2000-2001. "Die Legende 'Barlaam und Josaphat' in der arabischmuslimischen Literatur. Ein arabistischer Beitrag zur 'Barlaam-Frage'.” Die Welt des Orients 31: 110-44.

Tsugitaka, Sato. 2007. "The Sufi Legend of Sultan Ibrāhīm b. Adham." Orient 42: 41-54. Van Bladel, Kevin. 2011. "The Bactrian Background of the Barmakids." In Islam and Tibet: Interactions along the Musk Routes, edited by Anna Akasoy, Charles Burnett, and Ronit Yoeli-Tlalim, 43-88. Farnham: Ashgate.

Vaziri, Mostafa. 2012. Buddhism in Iran: An Anthropological Approach to Traces and Influences. New York: Palgrave Macmillan.

Waardenburg, Jacques. 2003. Muslims and Others: Relations in Context. Berlin: De Gruyter. 
Webb, Russell. 1993. "The Early Spread and Influence of Buddhism in Western Asia." Buddhist Studies Review 10: 57-82.

Wheeler, Brannon. 2006. Mecca and Eden: Ritual, Relics, and Territory in Islam. Chicago: The University of Chicago Press.

Wink, André. 2002. Al-Hind: The Making of the Indo-Islamic World. Volume 1: Early Medieval India and the Expansion of Islam, $7^{\text {th }}-11^{\text {th }}$ Centuries. Boston: Brill.

Wymann-Landgraf, Umar F. Abd-Allah. 2013. Mālik and Medina: Islamic Legal Reasoning in the Formative Period. Leiden: Brill.

Xuanzang. 1884. Si-Yu-Ki: Buddhist Records of the Western World. Translated from the Chinese of Hiuen Tsiang (A.D. 629) by Samuel Beal. London: Kegan Paul.

Yusuf, Shaykh Hamza. 2010. “Buddha in the Qur'ān?" In Common Ground between Islam and Buddhism, edited by Reza Shah-Kazemi, 113-36. Louisville: Fons Vitae.

Zadeh, Travis. 2014. “Commanding Demons and Jinn. The Sorcerer in Early Islamic Thought." In No Tapping around Philology: A Festschrift in Honor of Wheeler Mclntosh Thackston Jr.'s $70^{\text {th }}$ Birthday, edited by Alireza Korangy and Dan Sheffield, 131-60. Wiesbaden: Harrassowitz.

Zysow, Aron. 2013. The Economy of Certainty: An Introduction to the Typology of Islamic Legal Theory. Atlanta: Lockwood Press. 